\title{
Stem Cell Therapy and Congenital Heart Disease
}

\author{
Timothy J. Nelson ${ }^{1,2,3,4}$ and Susana Cantero Peral 1,4,* \\ 1 Division of General Internal Medicine, Mayo Clinic, Rochester, MN 55905, USA; \\ canteroperal.susana@mayo.edu \\ 2 Department of Molecular Pharmacology and Experimental Therapeutics, Mayo Clinic, \\ Rochester, MN 55905, USA \\ 3 Transplant Center, Mayo Clinic, Rochester, MN 55905, USA \\ 4 Center for Regenerative Medicine, Mayo Clinic, Rochester, MN 55905, USA \\ * Correspondence: canteroperal.susana@mayo.edu; Tel.: +1-507-538-1496 \\ Academic Editor: Andy Wessels \\ Received: 14 April 2016; Accepted: 28 June 2016; Published: 5 July 2016
}

\begin{abstract}
For more than a decade, stem cell therapy has been the focus of intensive efforts for the treatment of adult heart disease, and now has promise for treating the pediatric population. On the basis of encouraging results in the adult field, the application of stem cell-based strategies in children with congenital heart disease (CHD) opens a new therapy paradigm. To date, the safety and efficacy of stem cell-based products to promote cardiac repair and recovery in dilated cardiomyopathy and structural heart disease in infants have been primarily demonstrated in scattered clinical case reports, and supported by a few relevant pre-clinical models. Recently the TICAP trial has shown the safety and feasibility of intracoronary infusion of autologous cardiosphere-derived cells in children with hypoplastic left heart syndrome. A focus on preemptive cardiac regeneration in the pediatric setting may offer new insights as to the timing of surgery, location of cell-based delivery, and type of cell-based regeneration that could further inform acquired cardiac disease applications. Here, we review the current knowledge on the field of stem cell therapy and tissue engineering in children with CHD, and discuss the gaps and future perspectives on cell-based strategies to treat patients with CHD.
\end{abstract}

Keywords: congenital heart disease; regenerative medicine; stem cell therapy; heart failure

\section{Introduction}

Congenital heart disease (CHD) represents a significant burden on the family and community despite considerable advances in surgical techniques and clinical management. CHD occurs in $\sim 7-8$ out of 1000 live births [1]. There is still substantial morbidity and mortality related with CHD—mainly with the severe forms-which constitutes the leading cause of mortality due to congenital malformations [2]. In the last decade, the improvement in the management of CHD in advanced societies has been realized in more adults with CHD than children. Recent estimations reveal that up to $80 \%$ of newborns and infants with CHD are likely to reach adulthood [2], which can result in a high likelihood for complications later in life. Progressive late heart failure in children and young adults has become a serious problem, with an overall mortality of 7\% in the United States [3]. The majority of these patients have CHD, with other causes being cardiomyopathy and myocarditis. In response to injury, the pediatric heart can undergo apoptosis, progressing to heart failure. Pressure overload in the children's right ventricle results in a substantial increase in the production of cardiac stem cells, suggesting an adaptive response in this cohort of patients. However, this innate regeneration may not be sufficient to address the challenges of severe CHD [4]. Progressive heart failure can be accelerated in severe forms of CHD within the first few years of life after several challenges-despite supportive treatment-eventually resulting in the requirement for a heart transplant. Unfortunately, the supply of 
available hearts remains small compared to the number of patients in need. Therefore, to improve the clinical outcomes of these patients, advanced technologies are urgently required. Furthermore, there are new cell-based technologies that could be used for CHD applications [5]. There is an emerging realization that cardiac regeneration can occur in children, and that children are likely to respond to cell-based cardiac regenerative methods.

This review article addresses the current knowledge in the new field of stem cell-based regenerative therapies and tissue engineering and their potential to treat children with CHD when benchmarked to the experience in the adult practice, and describes the gaps in knowledge in the field of CHD repairment.

\section{Stem Cells to Improve Cardiac Function in Adult Heart Disease}

There is extensive experience with multiple types of cell-based products that are in development to mitigate the effects of acute and chronic ischemic heart diseases in adult populations. In the last two decades, attempts to treat adult heart failure with stem cells-mainly involving the administration of autologous bone marrow derived stem cells (BMSC)—-have demonstrated a consistent safety profile without evidence of increased arrhythmogenicity or tumor formation. These results are highlighted in several published meta-analyses [6-14]. Stem cell therapy has shown promising results in adults with ischemic heart disease. However, these results have been inconsistent across a clinical spectrum of acquired heart disease. Besides the inconsistency in the results, various studies have shown sustained positive effects despite consistent evidence that infused or injected cells do not survive beyond 30 days in vivo. The use of stem cell therapy in adult heart disease has paved the road for the application of cell-based regenerative medicine in the pediatric setting.

Herein, we focus on the literature that reported on adults with heart disease that were treated using BMSC, to compare with current pediatric reports.

Strauer et al. [15] first reported intracoronary (IC) delivery of bone marrow-derived mononuclear cells (BM-MNCs) in acute ischemic patients in 2002. Following that trial, other clinical trials using BM-MNCs-including the TOPCARE-AMI trial [16,17], the BOOST trial [18-20], TCT-STAMI [21], REPAIR-AMI [22], ASTAMI [23,24], FINCELL [25], BALANCE [26], SCAMI [27], BONAMI [28], COMPARE-AMI [29], LateTIME [30], TIME [31], CARDIAC [32], IACT [33], TOPCARE-CHD [34], and STAR-heart [35] - have been conducted in acute and chronic ischemic heart disease settings. In Table 1 we show the feasibility, safety, and efficacy of these studies. These numerous clinical studies have demonstrated the safety of IC delivery of stem cells. Thousands of patients have been included in similar clinical trials and received the cells via IC infusion-the most common method of cell delivery in the clinical setting-which allows placement of the cells into myocardial regions. BMSC are the most broadly used stem cells in regenerative medicine since their discovery in the 1960s. They were first used in hematopoietic stem cell transplantation to replace diseased bone marrow. Bone marrow contains different types of hematopoietic and non-hematopoietic stem cells, resulting in a very useful source for its regenerative potential. Autologous BMSC are among the best described multipotent stem cells for transplantation because their use does not require immunosuppressive therapy and they are easily accessible. All the clinical studies reviewed herein involved autologous BMSC, with the majority being mononuclear cells. The main outcome is a high degree of confidence in the safety profile. These results are confirmed with numerous published meta-analyses (Table 2) $[9,10,13-15,36]$. Those studies concluded that there were no differences in major adverse events between bone marrow cell-treated and control groups, such as all-cause mortality, cardiac mortality, incidence of recurrent myocardial infarction, and in-stent thrombosis, a potential concern in patients treated with IC BMSC infusion. The incidence of other important clinical adverse outcomes-including target vessel revascularization and ventricular arrhythmia-also did not differ between groups. Some of the meta-analyses reviewed found that the number of adverse events were actually significantly lower in the cell therapy group $[9,10,13]$. 
Table 1. Literature review of intracoronary delivery of autologous bone marrow stem cells in adult patients with ischemic heart disease.

\begin{tabular}{|c|c|c|c|c|c|c|}
\hline Study & Patients/Control & $\begin{array}{c}\text { Study } \\
\text { Design }\end{array}$ & $\begin{array}{l}\text { Cell Type } \\
\text { Infused }\end{array}$ & $\begin{array}{l}\text { Days from Disease } \\
\text { to Cells Infusion }\end{array}$ & $\begin{array}{l}\text { Follow-up } \\
\text { (Months) }\end{array}$ & Efficacy Outcomes \\
\hline Strauer et al., 2002 [15] & $10 / 10$ & $\mathrm{C}$ & MNCs & $5-9$ days & 3 & $\begin{array}{l}\text { No significant LVEF improvement vs. control. Significant } \\
\text { improvement with regard to infarct region, hemodynamics, cardiac } \\
\text { geometry, and contractility. }\end{array}$ \\
\hline \multicolumn{7}{|c|}{ TOPCARE-AMI trial } \\
\hline Assmus et al., 2002 [16] & $9(\mathrm{BM}) / 11(\mathrm{~PB})$ & R-NC & $\begin{array}{l}\text { BM-MNCs } \\
\& \text { PB-MNCs }\end{array}$ & $4.3 \pm 1.5$ days & 4 & $\begin{array}{l}\text { LVEF: cell therapy group > non-randomized matched } \\
\text { reference group. } \\
\text { No difference in LVEF between BM and PB groups. }\end{array}$ \\
\hline Schachinger et al., 2004 [17] & $29(\mathrm{BM}) / 30(\mathrm{~PB})$ & $\mathrm{R}-\mathrm{NC}$ & $\begin{array}{l}\text { BM-MNCs } \\
\& \text { PB-MNCs }\end{array}$ & $4.9 \pm 1.5$ days & 12 & $\begin{array}{l}\text { Cell therapy was associated with significant improvements in LVEF, } \\
\text { and significant reductions in LV end-systolic volumes after one year } \\
\text { of myocardial infarction. }\end{array}$ \\
\hline \multicolumn{7}{|c|}{ BOOST trial } \\
\hline Wollert et al., 2004 [20] & $30 / 30$ & $\mathrm{RC}$ & MNCs & $4.8 \pm 1.3$ days & 6 & Improvement in LVEF in bone marrow group. \\
\hline Meyer et al., 2006 [18] & $30 / 30$ & $\mathrm{RC}$ & MNCs & $4.8 \pm 1.3$ days & 18 & $\begin{array}{l}\text { BM group showed improvement in LVEF at } 6 \text { months, not } \\
\text { sustainable after } 18 \text { months. }\end{array}$ \\
\hline Meyer et al., 2009 [19] & $30 / 30$ & $\mathrm{RC}$ & MNCs & $4.8 \pm 1.3$ days & $\begin{array}{l}60(28 / 28 \\
\text { patients })\end{array}$ & $\begin{array}{l}\text { There is an early improvement of diastolic function without a } \\
\text { sustained effect on long-term follow-up. }\end{array}$ \\
\hline \multicolumn{7}{|c|}{ TCT-STAMI } \\
\hline Ge et al., 2006[21] & $10 / 10$ & $\mathrm{R}-\mathrm{CDB}$ & MNCs & 1 day & 6 & BM cells after AMI improved cardiac function. \\
\hline \multicolumn{7}{|c|}{ REPAIR-AMI trial } \\
\hline Assmuss et al., 2010 [22] & $101 / 103$ & R-PCDB & MNCs & $4 \pm 1$ days & 24 & $\begin{array}{l}\text { Infusion of BM cells improved LV contractile function and protected } \\
\text { against heart failure in the } 2 \text { years after stem cell therapy. }\end{array}$ \\
\hline \multicolumn{7}{|c|}{ ASTAMI } \\
\hline $\begin{array}{l}\text { Lunde et al., } 2008[24] \\
\text { Beitnes et al., } 2011 \text { [23] }\end{array}$ & $50 / 50$ & R-PC & MNCs & 6 days & $6,12,36$ & $\begin{array}{l}\text { At } 3 \text { years, it was just found a small improvement in exercise time in } \\
\text { the BM group, with no other remarkably signs of improvement. }\end{array}$ \\
\hline \multicolumn{7}{|c|}{ FINCELL } \\
\hline Huikuri et al., 2008 [25] & $40 / 40$ & R-PC & MNCs & $2-6$ days & 6 & $\begin{array}{l}\text { At } 6 \text { months, LVEF increased in the BM group compared with the } \\
\text { placebo group. }\end{array}$ \\
\hline \multicolumn{7}{|c|}{ BALANCE } \\
\hline Yousef et al., 2009 [26] & $62 / 62$ & $\mathrm{C}$ & MNCs & $7 \pm 2$ days & $3,12,60$ & $\begin{array}{l}\text { At 3-months follow-up, BM group showed a significant } \\
\text { improvement of LVEF and stroke volume index. The infarct size was } \\
\text { significantly reduced by } 8 \% \text {. Those parameters were stable at } 12 \text { and } \\
60 \text { months. The mortality was significantly reduced in the BM cell } \\
\text { therapy group compared with the control group. }\end{array}$ \\
\hline
\end{tabular}


Table 1. Cont.

\begin{tabular}{|c|c|c|c|c|c|c|}
\hline Study & Patients/Control & $\begin{array}{c}\text { Study } \\
\text { Design }\end{array}$ & $\begin{array}{l}\text { Cell Type } \\
\text { Infused }\end{array}$ & $\begin{array}{l}\text { Days from Disease } \\
\text { to Cells Infusion }\end{array}$ & $\begin{array}{l}\text { Follow-up } \\
\text { (Months) }\end{array}$ & Efficacy Outcomes \\
\hline \multicolumn{7}{|c|}{ SCAMI } \\
\hline Wohrle et al., 2013 [27] & $29 / 13$ & R-PCDB & MNCs & $5-7$ days & $1,3,6,36$ & $\begin{array}{l}\text { Improvement in LVEF up to } 3 \text { years in patients who received high } \\
\text { doses of BM cells or without microvascular obstruction. }\end{array}$ \\
\hline \multicolumn{7}{|c|}{ BONAMI } \\
\hline Roncalli et al., 2011 [28] & $52 / 49$ & $\mathrm{RC}$ & MNCs & $9.3 \pm 1.7$ days & 3 & Improvement of myocardial viability in multivariate analysis. \\
\hline \multicolumn{7}{|c|}{ COMPARE-AMI } \\
\hline Mansour et al., 2011 [29] & $20 / 20$ & $\mathrm{R}-\mathrm{CDB}$ & MNCs-CD133+ & $6.4 \pm 2.2$ days & 12 & $\begin{array}{l}\text { LVEF significantly improved at four months of follow up and } \\
\text { remained higher at } 12 \text { months. }\end{array}$ \\
\hline \multicolumn{7}{|c|}{ LateTIME } \\
\hline Traverse et al., 2011 [30] & $58 / 29$ & R-PCDB & MNCs & 14-21 days & 6 & No improvement in regional function or LVEF. \\
\hline \multicolumn{7}{|c|}{ TIME } \\
\hline Traverse et al., 2012 [31] & $\begin{array}{l}3 \text { days: } 43 / 24 \\
7 \text { days: } 36 / 17\end{array}$ & R-PCDB & MNCs & 3 vs. 7 & 6 & No differences on LVEF between BM and placebo groups. \\
\hline \multicolumn{7}{|c|}{ CARDIAC } \\
\hline Piepoli et al., 2013 [32] & $19 / 19$ & $\mathrm{RC}$ & $\begin{array}{l}\text { CD } 45+\& \\
\text { MNCs }\end{array}$ & 4 days & $3,6,12,24$ & $\begin{array}{l}\text { Significant improvement in LVEF at } 12 \text { month follow-up in the BM } \\
\text { group, not found at } 24 \text { months. }\end{array}$ \\
\hline \multicolumn{7}{|c|}{ IACT } \\
\hline Strauer et al., 2005 [33] & $18 / 18$ & C & MNCs & 3 months to 9 years & 3 & $\begin{array}{l}\text { Improvement in LVEF and reduced infarct size by } 30 \% \text { in the } \\
\text { BM group. }\end{array}$ \\
\hline \multicolumn{7}{|c|}{ TOPCARE-CHD } \\
\hline Assmus et al., 2006 [34] & 24/28/23/PB/BM/Control & RCC & $\begin{array}{l}\text { PB-MNCs \& } \\
\text { BM-MNCs }\end{array}$ & $\begin{array}{c}>90 \text { days } \\
(2470 \pm 2196 \text { days })\end{array}$ & 3 & $\begin{array}{l}\text { Significant improvement in LVEF in the BM group at 3-month } \\
\text { follow-up. No improvement in the PB group when compared } \\
\text { with placebo. }\end{array}$ \\
\hline \multicolumn{7}{|c|}{ STAR-heart } \\
\hline Strauer et al., 2010 [35] & $191 / 200$ & C & MNCs & $8.5 \pm 3.2$ years & $3,12,60$ & $\begin{array}{l}\text { At 5-year follow-up, improvement in LVEF and increased survival } \\
\text { in the BM group. }\end{array}$ \\
\hline
\end{tabular}


Table 2. Summary of meta-analysis studies for intracoronary stem cell transplantation in acute ischemic heart disease.

\begin{tabular}{|c|c|c|c|c|c|c|c|}
\hline Authors/Year & Disease & $\begin{array}{l}\text { Number of } \\
\text { Studies } \\
\text { Included }\end{array}$ & $\begin{array}{l}\text { Study } \\
\text { Design }\end{array}$ & $\begin{array}{l}\text { Total \# of Patients } \\
\text { Included }\end{array}$ & Cell Type & Follow-up Duration & $\begin{array}{l}\text { Major Adverse Events in } \\
\text { Stem Cell Group } \\
\text { Compared with Controls }\end{array}$ \\
\hline $\begin{array}{c}\text { Gyongyosi et al., } \\
2015[8]\end{array}$ & AMI & 12 & RCT & 1252 & $\begin{array}{l}\text { BM-MNCs }(n=11) \\
\text { Cardiosphere-derived cells }(n=1)\end{array}$ & Mean: 3-12 months & No (1) \\
\hline $\begin{array}{l}\text { de Jong R et al., } \\
2014 \text { [6] }\end{array}$ & AMI & 30 & RCT & $\begin{array}{l}2037 \text { (1218 cell } \\
\text { therapy vs. } \\
819 \text { controls) }\end{array}$ & $\begin{array}{c}\text { BM-MNCs }(n=22) \\
\text { MSCs }(n=3) \\
\text { BM CD133+ CD34+ }(n=4) \\
\text { Cardiosphere-derived cells }(n=1)\end{array}$ & Median: 6 months & No (2) \\
\hline Delewi et al., 2014 [7] & AMI & 16 & RCT & $\begin{array}{l}1641 \text { (984 cell } \\
\text { therapy vs. } \\
657 \text { controls) }\end{array}$ & $\begin{array}{c}\text { BM-MNCs }(n=13) \\
\text { BM-CD34+/CXCR4+ }(n=1) \\
\text { Nucleated BM cells }(n=2)\end{array}$ & 3-6 months & No (3) \\
\hline $\begin{array}{c}\text { Jeevanantham et al., } \\
2012[9]\end{array}$ & $\begin{array}{l}\text { IHD (AMI \& } \\
\text { CIHD) }\end{array}$ & $\begin{array}{l}50 \text { (38 IC vs. } \\
\quad 12 \text { IM) }\end{array}$ & $\begin{array}{l}\mathrm{RCT}(n=36) \\
\operatorname{CS}(n=14)\end{array}$ & 2625 & $\begin{array}{c}\text { BM-MNCs }(n=36) \\
\text { BM-CD34+ and or CD133+ }(n=6) \\
\text { Nucleated BM cells }(n=5) \\
\text { BM-MSC and /or endothelial } \\
\text { progenitor cells }(n=3)\end{array}$ & 3-60 months & No $(4)$ \\
\hline $\begin{array}{l}\text { Zimmet et al., } \\
2012[14]\end{array}$ & AMI & $\begin{array}{c}29 \text { (23 IC vs. } \\
6 \text { G-CSF trials) }\end{array}$ & RCT & $\begin{array}{l}1830 \text { ( } 1470 \text { from } \\
\text { IC trials) }\end{array}$ & BM stem cells & $\begin{array}{l}\text { Short-term (3-6 months) } \\
\text { Long-term (12-18 months) }\end{array}$ & No (5) \\
\hline Ye et al., 2012 [12] & AMI & 10 & RCT & $\begin{array}{l}757 \text { ( } 394 \text { cell } \\
\text { therapy vs. } \\
363 \text { controls) }\end{array}$ & BM-MNCs & Mean: $1-5$ years & No (6) \\
\hline Zhang et al., 2009 [13] & AMI & 8 & RCT & 525 & BM stem cells & $1-5$ years & No (7) \\
\hline $\begin{array}{c}\text { Martin-Rendon et al., } \\
2008 \text { [11] }\end{array}$ & AMI & 13 & RCT & 811 & BM-MNCs & 3-6 months & No \\
\hline $\begin{array}{l}\text { Lipinski et al., } \\
2007 \text { [10] }\end{array}$ & AMI & 10 & $\begin{array}{c}\text { Controlled } \\
\text { trials }\end{array}$ & 698 & $\begin{array}{c}\text { BM stem cells }(n=8) \\
\text { PB mononuclear cells }(n=2)\end{array}$ & 3-18 months & No $(8)$ \\
\hline
\end{tabular}

AMI: acute myocardial infarction; IHD: ischemic heart disease; CIHD: chronic ischemic heart disease; IC: intracoronary; IM: intramyocardial; BM: bone marrow; RCT: randomized controlled trials; CS: cohort studies; BM-MNCs: bone marrow mononuclear cells; BM-MSCs: bone marrow mesenchymal stem cells; PB: peripheral blood; MI: myocardial infarction; LVEF: left ventricular ejection fraction. (1) This meta-analysis of individual patient data revealed that IC cell therapy provided no benefit, in terms of clinical events or changes in LVF (2) IC infusion of BM-MNCs is safe, but does not enhance cardiac function of MRI-derived parameters, nor does it improve clinical outcome; (3) IC BMC therapy leads to a modest but significant improvement of LVEF. Patients of younger age and with a more severely depressed LVEF showed the largest benefit; (4) BM cells transplantation reduced the incidence of death, recurrent MI, and stent thrombosis; (5) Lower revascularization rates with IC BM stem cells vs. control; (6) Sustained and moderate improvements of LVEF and attenuations of infarct size; (7) BM cell group significantly reduced the risk of death; (8) BM cell group showed a trend to reduce major adverse events. 
In a recently published meta-analysis [8], the safety and efficacy of IC cell therapy after acute myocardial infarction (AMI) have been analyzed, including individual patient data $(n=1252)$ from 12 randomized clinical trials. Except for one study, all patients received BM-MNCs. As found in other meta-analyses published before, there was no effect of cell therapy on major adverse cardiac and cerebrovascular events, or death. However, regarding efficacy, this first prospectively declared collaborative multinational database has revealed that IC cell therapy provided no clinical benefit or changes in left ventricular function. Another meta-analysis reported by de Jong et al. [6] —where 2037 patients were included from 30 randomized controlled trials-proved cell therapy also to be safe. BM-MNC therapy showed a slight improvement in left ventricular ejection fraction (LVEF), mainly because of a sustained left ventricular end-systolic volume (LVESV), along with a reduced infarct size. However, when those studies were analyzed using cardiac magnetic resonance imaging-based measurements, no functional improvements in cardiac function, volume, or infarct size were demonstrated. In previous meta-analyses, IC infusion of BM-MNCs resulted in a mild-moderate cardiac function after acute ischemic disease. When newer large randomized controlled clinical trials restricted to patients with AMI were included in the latest meta-analyses, the IC infusion of BM-MNCs did not show an improvement of cardiac function or a reduction of all-cause mortality, cardiac mortality, or recurrent AMI hospitalizations for either cardiac or neurologic complications.

These efforts and the contradictory results have led to a large European multicenter, randomized open-label, controlled, parallel-group phase III trial (BAMI study-NCT01569178). The aim of this definitive study for adult patients is to demonstrate that a single intracoronary infusion of autologous BM-MNCs is safe and reduces all-cause mortality in adults with reduced LVEF ( $\leqslant 45 \%)$ after successful reperfusion for AMI when compared to a control group of patients undergoing the best medical care. This study plans to enroll 3000 patients.

From a total of 45 thoroughly-reviewed clinical trials with more than 2000 patients included-the majority being randomized controlled trials-we herein highlight three of these studies based on the existing heart disease of the patients enrolled in the studies, cell-based products, and delivery strategies relevant to the documented pediatric experience [37-40] (Table 3). The patients included in these three clinical studies had non-ischemic heart diseases; in two cases they suffered from non-ischemic idiopathic dilated cardiomyopathy (DCM), and in one case from chronic chagasic cardiomyopathy. In two of those studies, BM-MNCs (unfractionated bone marrow) were used as the cell therapy, equivalent to the majority of pediatric clinical cases reported in the literature. Similar to reported results in previous clinical trials with ischemic patients, there was no increase in mortality or severe adverse events in the bone marrow cell-treated group. In the ABCD study [38,39], at three-year follow-up there was significant sustained improvement of LVEF. The Miheart-Chagas study [37] did not demonstrate any improvement in LVEF in the stem cell therapy group, with similar mortality in both groups. The main outcome showed by Vrtovec et al. was that in the bone marrow cell group, the total mortality was lower when compared with the control group after 60 months of follow-up $(14 \%$ vs. $31 \%, p=0.01)$. Overall, the reported safety results have been similar between non-ischemic heart patients and ischemic heart populations. 
Table 3. Randomized controlled studies with bone marrow mononuclear cells for intracoronary delivery in adults with non-ischemic cardiomyopathies.

\begin{tabular}{|c|c|c|c|c|c|c|c|}
\hline Study & Patients/Controls & Disease & $\begin{array}{c}\text { Study } \\
\text { Design }\end{array}$ & $\begin{array}{c}\text { Cell Type } \\
\text { and Dosage }\end{array}$ & $\begin{array}{c}\text { Time from Disease to } \\
\text { BM Infusion }\end{array}$ & $\begin{array}{c}\text { Follow-up } \\
\text { (Months) }\end{array}$ & Outcome \\
\hline \multicolumn{8}{|l|}{$\mathrm{ABCD}$ trial } \\
\hline Seth et al., 2010 [38] & $45 / 40$ & $\begin{array}{c}\text { Non-ischemic } \\
\text { idiopathic DCM }\end{array}$ & $\mathrm{RC}$ & MNCs $1.68 \times 10^{8}$ & $>6$ months & 36 & $\begin{array}{l}\text { LVEF improved in the BM group by } 5.9 \% \text { from } \\
6 \text {-month follow-up with a reduction in end-systolic } \\
\text { volumes and no change in end-diastolic volumes. }\end{array}$ \\
\hline \multicolumn{8}{|l|}{ Miheart-Chagas } \\
\hline $\begin{array}{l}\text { Ribeiro dos Santos et al., } \\
2012[37]\end{array}$ & $117 / 117$ & $\begin{array}{l}\text { Chronic chagasic } \\
\text { cardiomyopathy }\end{array}$ & R-PC & MNCs $2.2 \times 10^{8}$ & Not available & 6,12 & $\begin{array}{l}\text { No improvement in LVEF } \\
\text { Mortality was similar in both groups } \\
\text { Intracoronary BM stem cell infusion was associated }\end{array}$ \\
\hline Vrtovec et al., 2013 [40] & $55 / 55$ & $\begin{array}{c}\text { Non-ischemic } \\
\text { DCM }\end{array}$ & $\mathrm{RC}$ & $\begin{array}{l}\text { MNCs CD34+ } \\
113 \pm 26 \times 10^{6}\end{array}$ & $>3$ months & 60 & $\begin{array}{l}\text { with improved LVEF, exercise tolerance, and } \\
\text { long-term survival at 5-year follow-up, and lower } \\
\text { total mortality, when compared with control group. }\end{array}$ \\
\hline
\end{tabular}




\section{Cell-Based Therapy Experience in Patients with CHD or Heart Failure}

On the basis of the experience and early results in adult patients, as we mentioned above, the application of stem cells to patients with CHD creates the opportunity to explore a new therapeutic paradigm.

Experience with stem cell therapy in children with severe congenital or acquired heart failure is not extensive (Table 4). To date, no large clinical trials have been published using stem cells to repair CHD. Most of the reports published used BMSC via IC infusions. To date, the two pediatric populations targeted to receive cardiac cell therapy have been patients with DCM and patients with single ventricle congenital heart defects. The first case reports using stem cell therapy in children with CHD were based on the extensive experience in adults with reduced left ventricle systolic function. However, the main causes of children's heart damage and heart failure are very different from those that cause heart failure in the adult population, who typically have multiple comorbidities. Pediatric heart diseases are more commonly secondary to CHD, infections, inflammation, cytotoxicity, or immune disorders. It is important to emphasize that pediatric patients can present with dilated and poorly functioning hearts, yet recover dramatically over a period of months with supportive care when the etiology is myocarditis, as opposed to adult patients. In the cases discussed in this review, none of the patients treated with cell therapy had myocarditis. Therefore, parameters such as age of individual, stem cell delivery strategy, and disease status, could lead to distinctive performance features of cell-based technologies.

The first case of cell-based therapy in a child with DCM was reported by Rupp et al. in 2009 [41]. The authors reported that IC injection of BM-MNCs was safe and feasible. The LVEF improved from $24 \%$ to $45 \%$ after 6 months of cell injection. One year later, the same group published a new case report of cell therapy in an 11-month-old patient. There were no complications during the cell infusion and no adverse events were reported. At 3-months follow-up, the cardiac function had improved, showing a reduction of end-diastolic and end-systolic volumes [42]. Most recently, Rupp et al. [43] reported the results of IC BM-MNCs delivery for terminal heart failure in nine children to stabilize the end-stage heart failure condition of all patients as compassionate use. Two-thirds of the patients suffered from DCM and one-third was affected with CHD. Moderate ST-segment changes were reported during stem cell delivery. However, no increase in cardiac enzymes or unexpected adverse events were observed after the procedure. After donor organs became available, two patients proceeded to heart transplantation (at 48 and 32 days after cell therapy), before the efficacy of the procedure could be demonstrated. Three patients with DCM and two patients with CHD benefited from autologous infusion of BMSC. They showed an improvement in their clinical condition, and in LVEF.

In 2010, Olguntürk et al. [44] published a report of two pediatric patients with DCM who received peripheral blood-derived mononuclear cells after granulocyte-colony stimulating factor (G-CSF) via the coronary arteries. Both cases were referred to the clinic for cardiac transplantation due to end-stage heart failure that was resistant to drugs. The cells were collected by leukopheresis after the patients received G-CSF (10 ug/ $\mathrm{kg} /$ day) for four days, until the CD34+ cell count reached $30 \times 10^{9} / \mathrm{L}$. Total mononuclear cells infused were $1.96 \times 10^{6} / \mathrm{kg}$ and $1.27 \times 10^{6} / \mathrm{kg}$, respectively. In patient one, auto-limited ventricular tachycardia was observed during the procedure, probably related with rapid infusion. No other adverse events were observed in either patient. Five weeks after the cell infusion, the patients' clinical status improved considerably in parallel to the echocardiographic results. At eight weeks, patient one went from 16\% of LVEF (at time of admission) to 39\%, and patient two from $34 \%$ to $51 \%$. At six months, patient two showed an LVEF of $54 \%$, and this patient was removed from the heart transplantation list with New York Heart Association (NYHA) class I status.

In 2011, Lacis et al. [45] reported—for the first time-the intramyocardial administration of autologous BM-MNCs in a four-month-old infant with severe DCM. At four-month follow-up, the LVEF had increased from $20 \%$ (before stem cell transplantation) to $41 \%$. 
Table 4. Case reports and clinical trials of stem cell-based therapy in children with CHD and/or heart failure.

\begin{tabular}{|c|c|c|c|c|c|c|c|c|}
\hline Study/Author & No of Patients & Age of Patients & Entity Cardiac Status & Study Design & Cell Type and Cell Dose & $\begin{array}{l}\text { Delivery } \\
\text { Route }\end{array}$ & Follow-up & Outcomes \\
\hline Rupp S et al., 2009 [41] & 1 & 2 years & $\mathrm{DCM}$ & Case report & $\begin{array}{c}\text { Autologous BM-MNCs/ } \\
20 \times 10^{6} \text { cells } / \mathrm{kg}\end{array}$ & IC & 6 months & $\begin{array}{c}\text { Safe and feasible } \\
\uparrow \text { LVEF } \\
\downarrow \text { NYHA } \\
\downarrow \text { BNP }\end{array}$ \\
\hline Rupp S et al., 2010 [42] & 1 & 11 months & $\begin{array}{l}\text { HLHS + mitral } \\
\text { stenosis + aortic } \\
\text { atresia }\end{array}$ & Case report & Autologous BM-MNCs & IC & 3 months & $\begin{array}{c}\text { Safe and feasible } \\
\uparrow \text { LVEF } \\
\downarrow \text { BNP } \\
\end{array}$ \\
\hline Rupp S et al., 2012 [43] & 9 & $\begin{array}{l}4 \text { months-16 } \\
\text { years }\end{array}$ & $\begin{array}{l}\mathrm{DCM}(n=6) \text { and } \\
\mathrm{CHD}(n=3)\end{array}$ & Cohort & Autologous BM-MNCs & IC & 24-52 months & $\begin{array}{c}1 \mathrm{pt}=\text { death no } \\
\text { procedure-related } \\
3 \mathrm{pts}=\text { heart Tx } \\
5 \mathrm{pts}= \\
\uparrow \mathrm{LVEF} \\
\downarrow \text { NYHA } \\
\downarrow \text { BNP }\end{array}$ \\
\hline Olguntürk et al., 2010 [44] & 2 & 6 years, 9 years & DCM & Case reports & $\begin{array}{c}\text { Autologous PB-MNCs mobilized } \\
\text { with G-CSF } / 1.96 \text { and } \\
1.27 \times 10^{6} \text { cells } / \mathrm{kg}\end{array}$ & IC & $2-6$ months & $\begin{array}{c}\uparrow \text { LVEF } \\
\downarrow \text { NYHA } \\
\downarrow \text { BNP } \\
1 \text { pt was removed } \\
\text { of the heart Tx list }\end{array}$ \\
\hline Lacis A et al., 2011 [45] & 1 & 4 months & $\mathrm{DCM}$ & Case report & Autologous BM-MNCs & $\mathrm{IM}$ & 4 months & $\uparrow \mathrm{LVEF}$ \\
\hline $\begin{array}{l}\text { Bergmane I et al., } \\
2013 \text { [46] }\end{array}$ & $\begin{array}{l}7 \text { (6 completed } \\
\text { follow-up) }\end{array}$ & $\begin{array}{l}4 \text { months- } 17 \\
\text { years }\end{array}$ & DCM & Cohort & Autologous BM-MNCs & IC & 12 months & $\begin{array}{c}\text { Safe and feasible } \\
\uparrow \text { LVEF } \\
\downarrow \text { LVEDV } \\
\end{array}$ \\
\hline $\begin{array}{l}\text { Limsuwan A et al., } \\
2010[47]\end{array}$ & 1 & 9 years & CHF after MI & Case report & $\begin{array}{c}\text { Autologous BM-CD133+/CD34+ } \\
\text { mobilized with G-CSF }\end{array}$ & IC & 3 months & $\begin{array}{l}\uparrow \mathrm{LVEF} \\
\downarrow \mathrm{NYHA} \\
\end{array}$ \\
\hline $\begin{array}{l}\text { Burkhart H et al., } \\
2014 \text { [48] }\end{array}$ & 1 & 4 months & HLHS & Case report & $\begin{array}{l}\text { Autologous UCB-MNCs/ } \\
\quad 3 \times 10^{6} \text { cells } / \mathrm{kg}\end{array}$ & $\mathrm{IM}$ & 3 months & $\begin{array}{l}\downarrow \text { NYHA } \\
\uparrow \text { RVEF } \\
\downarrow \text { BNP }\end{array}$ \\
\hline $\begin{array}{l}\text { TICAP study, Okayama } \\
\text { University, Japan }\end{array}$ & $\begin{array}{c}14 \text { (7 cell therapy vs. } \\
7 \text { controls) }\end{array}$ & $\begin{array}{c}\leqslant 6 \text { years } \\
1.8 \pm 1.5 \text { years }\end{array}$ & HLHS & $\begin{array}{l}\text { Phase } 1 \text { Prospective, } \\
\text { controlled }\end{array}$ & $\begin{array}{l}\text { Autologous CDC/ } \\
0.3 \times 10^{6} \text { cells } / \mathrm{kg}\end{array}$ & IC & 36 months & $\begin{array}{c}\text { Safe and feasible } \\
\uparrow \text { RVEF } \\
\downarrow \text { BNP }\end{array}$ \\
\hline $\begin{array}{l}\text { PERSEUS trial, Okayama } \\
\text { University, Japan }\end{array}$ & 34 & $\leqslant 20$ years & $\begin{array}{l}\text { Univentricular heart } \\
\text { disease }\end{array}$ & $\begin{array}{l}\text { Phase } 2 \text { Prospective, } \\
\text { randomized-controlled }\end{array}$ & $\begin{array}{l}\text { Autologous CDC/ } \\
0.3 \times 10^{6} \text { cells } / \mathrm{kg}\end{array}$ & IC & 12 months & $\begin{array}{l}\text { Ongoing, but not } \\
\text { recruiting patients } \\
\text { NCT01829750 }\end{array}$ \\
\hline Mayo Clinic, USA & 10 & $\leqslant 18$ months & HLHS & Phase 1 & $\begin{array}{l}\text { Autologous UCB-MNCs/ } \\
\quad 3 \times 10^{6} \text { cells } / \mathrm{kg}\end{array}$ & IM & 6 months & $\begin{array}{l}\text { Recruiting patients } \\
\text { since } 2013 \\
\text { NCT01883076 }\end{array}$ \\
\hline
\end{tabular}


Table 4. Cont

\begin{tabular}{|c|c|c|c|c|c|c|c|c|}
\hline Study/Author & No of Patients & Age of Patients & Entity Cardiac Status & Study Design & Cell Type and Cell Dose & $\begin{array}{l}\text { Delivery } \\
\text { Route }\end{array}$ & Follow-up & Outcomes \\
\hline Duke University, USA & 20 & $\leqslant 2$ days & HLHS & Phase 1, randomized & $\begin{array}{l}\text { Autologous UCB cells } \\
5 \times 10^{7} \mathrm{TNC} \text { cells } / \mathrm{kg}\end{array}$ & IV & $\begin{array}{c}12 \text { months Focus } \\
\text { in neurologic } \\
\text { effects }\end{array}$ & $\begin{array}{l}\text { Ongoing, but not } \\
\text { recruiting patients } \\
\text { NCT01445041 }\end{array}$ \\
\hline $\begin{array}{l}\text { University of } \\
\text { Miami, USA }\end{array}$ & 30 & $\leqslant 28$ days & HLHS & $\begin{array}{l}\text { Phase } 1 \text {, randomized } \\
\text { after first } 10 \text { patients }\end{array}$ & $\begin{array}{l}\text { Allogeneic MSCs/ } \\
2.5 \times 10^{5} \text { cells } / \mathrm{kg}\end{array}$ & $\mathrm{IM}$ & 12 months & $\begin{array}{l}\text { Recruiting patients } \\
\text { since } 2015 \\
\text { NCT02398604 }\end{array}$ \\
\hline Mayo Clinic, USA & 10 & $2-30$ years & $\begin{array}{l}\text { Single RV failure due } \\
\text { to CHD }\end{array}$ & Phase 1 & $\begin{array}{l}\text { Autologous BM-MNCs/ } \\
3 \times 10^{6} \text { cells } / \mathrm{kg}\end{array}$ & IC & 24 months & $\begin{array}{l}\text { Recruiting patients } \\
\text { since } 2015 \\
\text { NCT02549625 }\end{array}$ \\
\hline
\end{tabular}


In 2013, Bergmane et al. [46] published the first pediatric cohort with a one-year follow-up of six patients out of seven that were diagnosed with DCM and received BMSC. Seventeen to $122 \times 10^{6}$ BMSC were isolated. There were no side effects upon cell delivery. The average basal LVEF was $33.5 \%$, and an increase of up to $54 \%$ was observed at 6-month and 12-month follow-up.

In 2010, the first pediatric case of transcoronary injection of bone marrow-derived progenitor cells for end-stage heart disease after a myocardial infarction was reported. The nine-year-old patient received bone marrow CD133+/CD34+ cells using a transcoronary catheter without any complication. Three months after the cell therapy treatment, the LVEF (by cardiac magnetic resonance and echocardiogram) improved from $30 \%$ at baseline to $47 \%$ [47].

Altogether, these first studies offer an encouraging perspective on the potential for first-generation stem cell therapy to be considered in the pediatric population as an adjunctive therapy to surgical management of CHD.

In March of 2013, our group launched the first USA-based stem cell trial for CHD (NCT01883076), with the main goal being the determination of the safety and feasibility of autologous umbilical cord blood (UCB)-derived stem cells for cardiac regeneration in children with HLHS. We have reported the first case of direct intramyocardial injection of umbilical cord blood-derived mononuclear cells (UCB-MNCs) in an infant with HLHS [48]. The UCB was collected at the time of delivery, and the MNCs fraction was isolated and stored in liquid nitrogen. The cells were injected into the right ventricle at the time of the Glenn procedure. No adverse events occurred either at the time of infusion or later. Transthoracic echocardiography at three months showed improvement in right ventricular systolic function, with an estimated ejection fraction of 50\%, increased from $30 \%-35 \%$ before surgery. Since 2015, our group has been conducting a phase I study (NCT02549625) to determine the safety and feasibility of intracoronary delivery of autologous BM-MNCs in individuals, from 2-30 years of age, with Fontan circulation and declining ventricle systemic pumps.

Since April 2013, a randomized-controlled, prospective phase II clinical trial has been conducted at Okayama University in Japan (PERSEUS-NCT01829750). The Cardiac Progenitor Cell Infusion to Treat Univentricular Heart Disease (PERSEUS) trial has been designed to assess the efficacy of intracoronary infusion of cardiac progenitor cells (CDCs) in young patients (up to 20 years of age) with univentricular heart disease (HLHS, single right ventricle and single left ventricle). A total of 34 patients are randomly assigned 1:1 to the treated or control group. Patients included in this study are in a preoperative high-risk group or did not recover cardiac function postoperatively, therefore, eventually their only option is heart transplantation. This phase II clinical study has been implemented following the safety verification of the previous phase I study (TICAP trial) completed in January 2013 by the same investigators, and published recently by Tarui et al. [49]. In this controlled study, 14 consecutive patients with HLHS were prospectively assigned to receive intracoronary CDCs one month after cardiac surgery $(n=7)$, followed by seven control patients who received standard care alone. The cell infusion was feasible and no serious adverse events were reported within 36 months of follow-up. Echocardiography showed a significant right ventricular ejection fraction (RVEF) improvement in those infants who received CDCs compared with the controls. Other ongoing clinical trials using stem cells in CHD include phase I trials at Duke University (NCT01445041) and at University of Miami (NCT02398604). The Duke study, which has temporarily suspended participant recruitment, is evaluating the safety and feasibility of collecting and infusing intravenously autologous UCB in newborns with HLHS. In addition, as a secondary goal, the investigators will evaluate the efficacy of the UCB-MNCs to improve the neurological function affected in these children. Recently, the University of Miami has begun enrollment of HLHS pediatric patients in a phase I trial to deliver intramyocardially allogeneic mesenchymal stem cells (MSCs) during the bi-directional cavopulmonary anastomosis surgery. Thirty patients are intended to be enrolled. The first 10 patients will receive allogeneic MSCs to determine feasibility and safety. The next 20 HLHS patients will be randomized to the treatment and control arms in a 1:3 ratio, respectively. 


\section{Translational Cell-Based Research for Cardiac Repair in CHD}

As the reported adult experience and pre-clinical studies [50-53] have shown us, cell-based regenerative therapies have been manufactured from a broad range of cell sources including bone marrow, cord blood, peripheral blood, and CDC. Beyond the first-generation of cell-based products, there is a growing list of cells, growth factors, and genetic engineering strategies that have been pioneered in the adult cardiac practice of regenerative medicine [54]. Cell-based products have been delivered either intra-myocardium or intra-coronary showing a safety range with no evidence of adverse events resultant to cell type or delivery strategy. Pediatric response to stem cells has resulted in measurable improvements in cardiac function, albeit in a limited number of patients to-date. It is almost impossible not to compare and contrast the adult and pediatric experiences in order to measure the magnitude of benefit that cell-based therapy could have for CHD. However, the main concern about this promising technology is the limited data due to the isolated cases reported. The clinical trials emerging will offer an equable protocol design and the ability to collect experimental evidence to advance research and clinical development utilizing regenerative strategies for CHD.

The potential of cell therapy in pediatric patients with CHD is enormous with different challenges not observed in adults. Due to the differences in pathobiology between the pediatric and adult cardiac diseases, it is difficult to anticipate the efficacy of stem cell therapy in CHD based on adult strategies, and thus it requires empiric testing in pre-clinical settings. With the new established large animal model systems we are able to carry out double-blinded, randomized studies to test safety and efficacy in the pediatric stages of disease.

Regarding the delivery strategy, the pediatric population with CHD requires multiple open-chest surgeries that allow for direct intramyocardial injection of stem cell-based products. Therefore, the delivery strategy in the diseased pediatric heart will be different than the usual intracoronary infusion in adults with ischemic heart disease, providing a focal and direct access to the myocardium.

As we described above, several types of stem cells are being used for cardiac regenerative medicine, and most of the clinical trials used in adult population have been conducted with autologous cells. This approach has the main advantage of avoiding immunologic reaction. In the pediatric population this is even more important, because a large number of these patients with CHD or acquired DCM could eventually require a heart transplant when the traditional and new therapeutic strategies are not effective. The chances to find a compatible donor if the patient has been sensitized with allogeneic antigens could be dramatically reduced. Furthermore, animal and clinical studies have demonstrated that aging interferes with progenitor cell functions and potency [55]. Stem cells from young individuals possess superior naivety and plasticity than stem cells from adults. Apoptosis and DNA damage increase in aging stem cells, and those defects can further reduce the pool of undifferentiated and progenitor cells. Edelberg et al. first reported that age directly affects cell-mediated improvement of new blood vessels, and demonstrated that young-not old-bone marrow cells were incorporated into the new vasculature and restored angiogenic cardiac functions [56]. Aging is also linked to a reduction of telomere length. The use of autologous cells in the pediatric setting-due the age of these patients—seems to be an advantage compared with older cells and better suited for regenerative purposes.

Fruitful regenerative strategies for pediatric patients with CHD should result in significant de novo cardiogenesis and remuscularization of the abated heart tissue. Uncertainty persists about the possible mechanisms by which stem cells might enhance cardiac function. Initially, it was believed that stem cells promoted cardiac differentiation by tissue replacement due to stem cell direct differentiation into cardiomyocytes [57]. More recently, several studies have revealed that first-generation cell-based product transplantation in heart disease stimulates an endogenous cardiac repair by releasing cytokines and growth factors following a paracrine effect $[58,59]$. Therefore, those cell products need to be prioritized in the pediatric setting. A paracrine effect added to the beneficial results of stem cell therapy supports the hypothesis that the combination of cytokines, chemokines and growth factors with cell therapy may have a synergistic effect on cardiac repair. Therapeutic interventions using just 
chemokines and growth factors are now the focus of subsequent investigations [60]. Based on this, these first-generation cell-based products may be sufficient to launch clinical services and provide clinically relevant results. Furthermore, second-generation products that include reprogrammed progenitor cells and/or combinations with biomaterials, still require testing in the pediatric population. The use of stem cells with biomaterials in the CHD setting may provide additional features in the context of reconstructive procedures. Finally, bioengineered pluripotent stem cells have proved to be the only type of stem cells able to remuscularize the heart muscle with de novo tissues. As high-risk structural heart defects in children mandate new functioning tissue, induced pluripotent stem cell-based strategies will likely provide the most meaningful strategy for a long-term functional cure and offer a unique opportunity to execute the first induced pluripotent stem cell-based clinical trial in a "no-option" population. Engineering strategies are needed to demonstrate the safety profile of pluripotent stem cells, along with pre-clinical testing in small and large animals prior to clinical studies.

CHD has now entered into the field of stem cell-based regenerative medicine. The emerging cell-based products and biomaterials have synergistic function, requiring safety and efficacy preclinical studies with the goal of moving towards innovative clinical trials. The need to apply the right cells, at the right time, to the right patient, will prioritize the experimental questions and experimental designs in the coming years, offering a new horizon for deterrent regenerative cardiac therapies.

\section{Conclusions}

In the field of CHD, several types of stem cells have been used with promising results. However, stem cell therapy strategies for the pediatric population with heart failure has just begun; therefore, further clinical trial studies will be needed to understand the cell biology in order to optimize their regenerative potential. The key to ideal cardiac regenerative cell therapy would be to combine different strategies, such as priming stem cells, combined with chemokines, and bio-engineering materials. Therefore, multiple cell-based products and strategies need to be evaluated head-to-head in specific pre-clinical models with clinically relevant delivery strategies to identify the optimal manufactured product for the right person at the right time. The challenge for the field of CHD regeneration is to build sustainable synergy between clinical practice and discovery science to prioritize the people, processes, and technology with a singular focus. This unmet clinical demand will need collaboration between academia, biobusiness companies, and governmental agencies to take advantage of the resources and expertise in order to safely translate research discoveries into clinical solutions and accelerate the next generation cell-based technologies for CHD.

Acknowledgments: Todd and Karen Wanek Family Program for Hypoplastic Left Heart Syndrome, Mayo Clinic Foundation. Center for Regenerative Medicine Career Development Award, Mayo Clinic Foundation.

Conflicts of Interest: The authors declare no conflict of interest.

\section{References}

1. Hoffman, J.I.; Kaplan, S. The incidence of congenital heart disease. J. Am. Coll. Cardiol. 2002, 39, 1890-1900. [CrossRef]

2. Khoshnood, B.; Lelong, N.; Houyel, L.; Thieulin, A.C.; Jouannic, J.M.; Magnier, S.; Delezoide, A.L.; Magny, J.F.; Rambaud, C.; Bonnet, D.; et al. Prevalence, timing of diagnosis and mortality of newborns with congenital heart defects: A population-based study. Heart 2012, 98, 1667-1673. [CrossRef] [PubMed]

3. Rossano, J.W.; Kim, J.J.; Decker, J.A.; Price, J.F.; Zafar, F.; Graves, D.E.; Morales, D.L.; Heinle, J.S.; Bozkurt, B.; Towbin, J.A.; et al. Prevalence, morbidity, and mortality of heart failure-related hospitalizations in children in the United States: A population-based study. J. Card. Fail. 2012, 18, 459-470. [CrossRef] [PubMed]

4. Rupp, S.; Bauer, J.; von Gerlach, S.; Fichtlscherer, S.; Zeiher, A.M.; Dimmeler, S.; Schranz, D. Pressure overload leads to an increase of cardiac resident stem cells. Basic Res. Cardiol. 2012, 107, 252. [CrossRef] [PubMed]

5. Bernstein, H.S.; Srivastava, D. Stem cell therapy for cardiac disease. Pediatr. Res. 2012, 71, 491-499. [CrossRef] [PubMed] 
6. De Jong, R.; Houtgraaf, J.H.; Samiei, S.; Boersma, E.; Duckers, H.J. Intracoronary stem cell infusion after acute myocardial infarction: A meta-analysis and update on clinical trials. Circ. Cardiovasc. Interv. 2014, 7, 156-167. [CrossRef] [PubMed]

7. Delewi, R.; Hirsch, A.; Tijssen, J.G.; Schachinger, V.; Wojakowski, W.; Roncalli, J.; Aakhus, S.; Erbs, S.; Assmus, B.; Tendera, M.; et al. Impact of intracoronary bone marrow cell therapy on left ventricular function in the setting of ST-segment elevation myocardial infarction: A collaborative meta-analysis. Eur. Heart J. 2014, 35, 989-998. [CrossRef] [PubMed]

8. Gyongyosi, M.; Wojakowski, W.; Lemarchand, P.; Lunde, K.; Tendera, M.; Bartunek, J.; Marban, E.; Assmus, B.; Henry, T.D.; Traverse, J.H.; et al. Meta-Analysis of Cell-based CaRdiac stUdiEs (ACCRUE) in patients with acute myocardial infarction based on individual patient data. Circ. Res. 2015, 116, 1346-1360. [CrossRef] [PubMed]

9. Jeevanantham, V.; Butler, M.; Saad, A.; Abdel-Latif, A.; Zuba-Surma, E.K.; Dawn, B. Adult bone marrow cell therapy improves survival and induces long-term improvement in cardiac parameters: A systematic review and meta-analysis. Circulation 2012, 126, 551-568. [CrossRef] [PubMed]

10. Lipinski, M.J.; Biondi-Zoccai, G.G.L.; Abbate, A.; Khianey, R.; Sheiban, I.; Bartunek, J.; Vanderheyden, M.; Kim, H.-S.; Kang, H.-J.; Strauer, B.E.; et al. Impact of intracoronary cell therapy on left ventricular function in the setting of acute myocardial infarction: A collaborative systematic review and meta-analysis of controlled clinical trials. J. Am. Coll. Cardiol. 2007, 50, 1761-1767. [CrossRef] [PubMed]

11. Martin-Rendon, E.; Brunskill, S.J.; Hyde, C.J.; Stanworth, S.J.; Mathur, A.; Watt, S.M. Autologous bone marrow stem cells to treat acute myocardial infarction: A systematic review. Eur. Heart J. 2008, 29, 1807-1818. [CrossRef] [PubMed]

12. Ye, Z.; Zhang, B.L.; Zhao, X.X.; Qin, Y.W.; Wu, H.; Cao, J.; Zhang, J.L.; Hu, J.Q.; Zheng, X.; $\mathrm{Xu}, \mathrm{R} . \mathrm{L}$. Intracoronary infusion of bone marrow-derived mononuclear cells contributes to longstanding improvements of left ventricular performance and remodelling after acute myocardial infarction: A meta-analysis. Heart Lung Circ. 2012, 21, 725-733. [CrossRef] [PubMed]

13. Zhang, C.; Sun, A.; Zhang, S.; Yao, K.; Wu, C.; Fu, M.; Wang, K.; Zou, Y.; Ge, J. Efficacy and safety of intracoronary autologous bone marrow-derived cell transplantation in patients with acute myocardial infarction: Insights from randomized controlled trials with 12 or more months follow-up. Clin. Cardiol. 2010, 33, 353-360. [CrossRef] [PubMed]

14. Zimmet, H.; Porapakkham, P.; Sata, Y.; Haas, S.J.; Itescu, S.; Forbes, A.; Krum, H. Short- and long-term outcomes of intracoronary and endogenously mobilized bone marrow stem cells in the treatment of ST-segment elevation myocardial infarction: A meta-analysis of randomized control trials. Eur. J. Heart Fail. 2012, 14, 91-105. [CrossRef] [PubMed]

15. Strauer, B.E.; Brehm, M.; Zeus, T.; Köstering, M.; Hernandez, A.; Sorg, R.V.; Kögler, G.; Wernet, P. Repair of infarcted myocardium by autologous intracoronary mononuclear bone marrow cell transplantation in humans. Circulation 2002, 106, 1913-1918. [CrossRef] [PubMed]

16. Assmus, B.; Schachinger, V.; Teupe, C.; Britten, M.; Lehmann, R.; Dobert, N.; Grunwald, F.; Aicher, A.; Urbich, C.; Martin, H.; et al. Transplantation of progenitor cells and regeneration enhancement in acute myocardial infarction (TOPCARE-AMI). Circulation 2002, 106, 3009-3017. [CrossRef] [PubMed]

17. Schachinger, V.; Assmus, B.; Britten, M.B.; Honold, J.; Lehmann, R.; Teupe, C.; Abolmaali, N.D.; Vogl, T.J.; Hofmann, W.K.; Martin, H.; et al. Transplantation of progenitor cells and regeneration enhancement in acute myocardial infarction: Final one-year results of the TOPCARE-AMI Trial. J. Am. Coll. Cardiol. 2004, 44, 1690-1699. [CrossRef] [PubMed]

18. Meyer, G.P.; Wollert, K.C.; Lotz, J.; Steffens, J.; Lippolt, P.; Fichtner, S.; Hecker, H.; Schaefer, A.; Arseniev, L.; Hertenstein, B.; et al. Intracoronary bone marrow cell transfer after myocardial infarction: Eighteen months' follow-up data from the randomized, controlled BOOST (BOne marrOw transfer to enhance ST-elevation infarct regeneration) trial. Circulation 2006, 113, 1287-1294. [CrossRef] [PubMed]

19. Meyer, J.S.; Shearer, R.L.; Capowski, E.E.; Wright, L.S.; Wallace, K.A.; McMillan, E.L.; Zhang, S.C.; Gamm, D.M. Modeling early retinal development with human embryonic and induced pluripotent stem cells. Proc. Natl. Acad. Sci. USA 2009, 106, 16698-16703. [CrossRef] [PubMed]

20. Wollert, K.C.; Meyer, G.P.; Lotz, J.; Ringes Lichtenberg, S.; Lippolt, P.; Breidenbach, C.; Fichtner, S.; Korte, T.; Hornig, B.; Messinger, D.; et al. Intracoronary autologous bone-marrow cell transfer after myocardial infarction: The BOOST randomised controlled clinical trial. Lancet 2004, 364, 141-148. [CrossRef] 
21. Ge, J.; Li, Y.; Qian, J.; Shi, J.; Wang, Q.; Niu, Y.; Fan, B.; Liu, X.; Zhang, S.; Sun, A.; et al. Efficacy of emergent transcatheter transplantation of stem cells for treatment of acute myocardial infarction (TCT-STAMI). Heart 2006, 92, 1764-1767. [CrossRef] [PubMed]

22. Assmus, B.; Rolf, A.; Erbs, S.; Elsasser, A.; Haberbosch, W.; Hambrecht, R.; Tillmanns, H.; Yu, J.; Corti, R.; Mathey, D.G.; et al. Clinical outcome 2 years after intracoronary administration of bone marrow-derived progenitor cells in acute myocardial infarction. Circ. Heart Fail. 2010, 3, 89-96. [CrossRef] [PubMed]

23. Beitnes, J.O.; Gjesdal, O.; Lunde, K.; Solheim, S.; Edvardsen, T.; Arnesen, H.; Forfang, K.; Aakhus, S. Left ventricular systolic and diastolic function improve after acute myocardial infarction treated with acute percutaneous coronary intervention, but are not influenced by intracoronary injection of autologous mononuclear bone marrow cells: A 3 year serial echocardiographic sub-study of the randomized-controlled ASTAMI study. Eur. J. Echocardiogr. 2011, 12, 98-106. [PubMed]

24. Lunde, K.; Solheim, S.; Forfang, K.; Arnesen, H.; Brinch, L.; Bjornerheim, R.; Ragnarsson, A.; Egeland, T.; Endresen, K.; Ilebekk, A.; et al. Anterior myocardial infarction with acute percutaneous coronary intervention and intracoronary injection of autologous mononuclear bone marrow cells: Safety, clinical outcome, and serial changes in left ventricular function during 12-months' follow-up. J. Am. Coll. Cardiol. 2008, 51, 674-676. [CrossRef] [PubMed]

25. Huikuri, H.V.; Kervinen, K.; Niemelä, M.; Ylitalo, K.; Säily, M.; Koistinen, P.; Savolainen, E.-R.; Ukkonen, H.; Pietilä, M.; Airaksinen, J.K.E.; et al. Effects of intracoronary injection of mononuclear bone marrow cells on left ventricular function, arrhythmia risk profile, and restenosis after thrombolytic therapy of acute myocardial infarction. Eur. Heart J. 2008, 29, 2723-2732. [CrossRef] [PubMed]

26. Yousef, M.; Schannwell, C.M.; Kostering, M.; Zeus, T.; Brehm, M.; Strauer, B.E. The BALANCE Study: Clinical benefit and long-term outcome after intracoronary autologous bone marrow cell transplantation in patients with acute myocardial infarction. J. Am. Coll. Cardiol. 2009, 53, 2262-2269. [CrossRef] [PubMed]

27. Wohrle, J.; von Scheidt, F.; Schauwecker, P.; Wiesneth, M.; Markovic, S.; Schrezenmeier, H.; Hombach, V.; Rottbauer, W.; Bernhardt, P. Impact of cell number and microvascular obstruction in patients with bone-marrow derived cell therapy: Final results from the randomized, double-blind, placebo controlled intracoronary Stem Cell therapy in patients with Acute Myocardial Infarction (SCAMI) trial. Clin. Res. Cardiol. 2013, 102, 765-770. [PubMed]

28. Roncalli, J.; Mouquet, F.; Piot, C.; Trochu, J.N.; Le Corvoisier, P.; Neuder, Y.; Le Tourneau, T.; Agostini, D.; Gaxotte, V.; Sportouch, C.; et al. Intracoronary autologous mononucleated bone marrow cell infusion for acute myocardial infarction: Results of the randomized multicenter BONAMI trial. Eur. Heart J. 2011, 32, 1748-1757. [CrossRef] [PubMed]

29. Mansour, S.; Roy, D.C.; Bouchard, V.; Stevens, L.M.; Gobeil, F.; Rivard, A.; Leclerc, G.; Reeves, F.; Noiseux, N. One-Year safety analysis of the COMPARE-AMI Trial: Comparison of intracoronary injection of CD133 ${ }^{+}$bone marrow stem cells to placebo in patients after acute myocardial infarction and left ventricular eysfunction. Bone Marrow Res. 2011, 2011, 385124. [CrossRef] [PubMed]

30. Traverse, J.H.; Henry, T.D.; Ellis, S.G.; Pepine, C.J.; Willerson, J.T.; Zhao, D.X.; Forder, J.R.; Byrne, B.J.; Hatzopoulos, A.K.; Penn, M.S.; et al. Effect of intracoronary delivery of autologous bone marrow mononuclear cells 2 to 3 weeks following acute myocardial infarction on left ventricular function: The LateTIME randomized trial. JAMA 2011, 306, 2110-2119. [CrossRef] [PubMed]

31. Traverse, J.H.; Henry, T.D.; Pepine, C.J.; Willerson, J.T.; Zhao, D.X.; Ellis, S.G.; Forder, J.R.; Anderson, R.D.; Hatzopoulos, A.K.; Penn, M.S.; et al. Effect of the use and timing of bone marrow mononuclear cell delivery on left ventricular function after acute myocardial infarction: The TIME randomized trial. JAMA 2012, 308, 2380-2389. [CrossRef] [PubMed]

32. Piepoli, M.F.; Vallisa, D.; Arbasi, C.; Cavanna, L.; Cerri, L.; Mori, M.; Passerini, F.; Tommasi, L.; Rossi, A.; Capucci, A. Two year follow-up results of the CARDIAC (CARDIomyoplasty by Autologous intraCoronary bone marrow in acute myocardial infarction) randomised controlled trial. Int. J. Cardiol. 2013, 168, e132. [CrossRef] [PubMed]

33. Strauer, B.E.; Brehm, M.; Zeus, T.; Bartsch, T.; Schannwell, C.; Antke, C.; Sorg, R.V.; Kogler, G.; Wernet, P.; Muller, H.W.; et al. Regeneration of human infarcted heart muscle by intracoronary autologous bone marrow cell transplantation in chronic coronary artery disease: The IACT Study. J. Am. Coll. Cardiol. 2005, 46, 1651-1658. [CrossRef] [PubMed] 
34. Assmus, B.; Honold, J.; Schächinger, V.; Britten, M.B.; Fischer-Rasokat, U.; Lehmann, R.; Teupe, C.; Pistorius, K.; Martin, H.; Abolmaali, N.D.; et al. Transcoronary transplantation of progenitor cells after myocardial infarction. N. Engl. J. Med. 2006, 355, 1222-1232. [CrossRef] [PubMed]

35. Strauer, B.E.; Yousef, M.; Schannwell, C.M. The acute and long-term effects of intracoronary Stem cell Transplantation in 191 patients with chronic heARt failure: The STAR-heart study. Eur. J. Heart Fail. 2010, 12, 721-729. [CrossRef] [PubMed]

36. Martin, M.; Reguero, J.J.; Calvo, D.; de la Torre, A.; Fernandez, A.; Castro, M.G.; de la Tassa, C.M.; del Valle, M. Prevalence of positive ECG criteria in young competitive athletes: A single region experience. Eur. Heart J. 2008, 29, 680-681. [CrossRef] [PubMed]

37. Ribeiro dos Santos, R.; Rassi, S.; Feitosa, G.; Grecco, O.T.; Rassi, A.; da Cunha, A.B.; de Carvalho, V.B.; Guarita-Souza, L.C.; de Oliveira, W.; Tura, B.R.; et al. Cell therapy in chagas cardiomyopathy (Chagas Arm of the Multicenter Randomized Trial of Cell Therapy in Cardiopathies Study): A multicenter randomized trial. Circulation 2012, 125, 2454-2461. [CrossRef] [PubMed]

38. Seth, S.; Bhargava, B.; Narang, R.; Ray, R.; Mohanty, S.; Gulati, G.; Kumar, L.; Airan, B.; Venugopal, P. The ABCD (Autologous Bone Marrow Cells in Dilated Cardiomyopathy) trial a long-term follow-up study. J. Am. Coll. Cardiol. 2010, 55, 1643-1644. [CrossRef] [PubMed]

39. Seth, S.; Narang, R.; Bhargava, B.; Ray, R.; Mohanty, S.; Gulati, G.; Kumar, L.; Reddy, K.S.; Venugopal, P. Percutaneous intracoronary cellular cardiomyoplasty for nonischemic cardiomyopathy: Clinical and histopathological results: The first-in-man ABCD (Autologous bone marrow cells in dilated cardiomyopathy) trial. J. Am. Coll. Cardiol. 2006, 48, 2350-2351. [CrossRef] [PubMed]

40. Vrtovec, B.; Poglajen, G.; Lezaic, L.; Sever, M.; Domanovic, D.; Cernelc, P.; Socan, A.; Schrepfer, S.; Torre-Amione, G.; Haddad, F.; et al. Effects of intracoronary CD $34^{+}$stem cell transplantation in nonischemic dilated cardiomyopathy patients: 5-year follow-up. Circ. Res. 2013, 112, 165-173. [CrossRef] [PubMed]

41. Rupp, S.; Bauer, J.; Tonn, T.; Schächinger, V.; Dimmeler, S.; Zeiher, A.M.; Schranz, D. Intracoronary administration of autologous bone marrow-derived progenitor cells in a critically ill two-yr-old child with dilated cardiomyopathy. Pediatr. Transpl. 2009, 13, 620-623. [CrossRef] [PubMed]

42. Rupp, S.; Zeiher, A.M.; Dimmeler, S.; Tonn, T.; Bauer, J.; Jux, C.; Akintuerk, H.; Schranz, D. A regenerative strategy for heart failure in hypoplastic left heart syndrome: Intracoronary administration of autologous bone marrow-derived progenitor cells. J. Heart Lung Transpl. 2010, 29, 574-577. [CrossRef] [PubMed]

43. Rupp, S.; Jux, C.; Bönig, H.; Bauer, J.; Tonn, T.; Seifried, E.; Dimmeler, S.; Zeiher, A.M.; Schranz, D. Intracoronary bone marrow cell application for terminal heart failure in children. Cardiol. Young 2012, 22, 558-563. [CrossRef] [PubMed]

44. Olgunturk, R.; Kula, S.; Sucak, G.T.; Ozdogan, M.E.; Erer, D.; Saygili, A. Peripheric stem cell transplantation in children with dilated cardiomyopathy: Preliminary report of first two cases. Pediatr. Transpl. 2010, 14, 257-260. [CrossRef]

45. Lacis, A.; Erglis, A. Intramyocardial administration of autologous bone marrow mononuclear cells in a critically ill child with dilated cardiomyopathy. Cardiol. Young 2011, 21, 110-112. [CrossRef] [PubMed]

46. Bergmane, I.; Lacis, A.; Lubaua, I.; Jakobsons, E.; Erglis, A. Follow-up of the patients after stem cell transplantation for pediatric dilated cardiomyopathy. Pediatr. Transpl. 2013, 17, 266-270. [CrossRef] [PubMed]

47. Limsuwan, A.; Pienvichit, P.; Limpijankit, T.; Khowsathit, P.; Hongeng, S.; Pornkul, R.; Siripornpitak, S.; Boonbaichaiyapruk, S. Transcoronary bone marrow-derived progenitor cells in a child with myocardial infarction: First pediatric experience. Clin. Cardiol. 2010, 33, E7-E12. [CrossRef] [PubMed]

48. Burkhart, H.M.; Qureshi, M.Y.; Peral, S.C.; O’Leary, P.W.; Olson, T.M.; Cetta, F.; Nelson, T.J. Regenerative therapy for hypoplastic left heart syndrome: First report of intraoperative intramyocardial injection of autologous umbilical-cord blood-derived cells. J. Thorac. Cardiovasc. Surg. 2015, 149, e35-e37. [CrossRef] [PubMed]

49. Tarui, S.; Ishigami, S.; Ousaka, D.; Kasahara, S.; Ohtsuki, S.; Sano, S.; Oh, H. Transcoronary infusion of cardiac progenitor cells in hypoplastic left heart syndrome: Three-year follow-up of the Transcoronary Infusion of Cardiac Progenitor Cells in Patients With Single-Ventricle Physiology (TICAP) trial. J. Thorac. Cardiovasc. Surg. 2015, 150, 1198.e2-1208.e2. [CrossRef] [PubMed] 
50. Cantero Peral, S.; Burkhart, H.M.; Oommen, S.; Yamada, S.; Nyberg, S.L.; Li, X.; O'Leary, P.W.; Terzic, A.; Cannon, B.C.; Nelson, T.J. Safety and feasibility for pediatric cardiac regeneration using epicardial delivery of autologous umbilical cord blood-derived mononuclear cells established in a porcine model system. Stem Cells Transl. Med. 2015, 4, 195-206. [CrossRef] [PubMed]

51. Davies, B.; Elwood, N.J.; Li, S.; Cullinane, F.; Edwards, G.A.; Newgreen, D.F.; Brizard, C.P. Human cord blood stem cells enhance neonatal right ventricular function in an ovine model of right ventricular training. Ann. Thorac. Surg. 2010, 89, 585.e4-593.e4. [CrossRef] [PubMed]

52. Oommen, S.; Yamada, S.; Peral, S.; Campbell, K.; Bruinsma, E.; Terzic, A.; Nelson, T. Human umbilical cord blood-derived mononuclear cells improve murine ventricular function upon intramyocardial delivery in right ventricular chronic pressure overload. Stem Cell Res. Ther. 2015, 6, 50. [CrossRef] [PubMed]

53. Yerebakan, C.; Sandica, E.; Prietz, S.; Klopsch, C.; Ugurlucan, M.; Kaminski, A.; Abdija, S.; Lorenzen, B.; Boltze, J.; Nitzsche, B.; et al. Autologous umbilical cord blood mononuclear cell transplantation preserves right ventricular function in a novel model of chronic right ventricular volume overload. Cell Transpl. 2009, 18, 855-868. [CrossRef] [PubMed]

54. Behfar, A.; Crespo-Diaz, R.; Terzic, A.; Gersh, B.J. Cell therapy for cardiac repair-Lessons from clinical trials. Nat. Rev. Cardiol. 2014, 11, 232-246. [CrossRef] [PubMed]

55. Dimmeler, S.; Leri, A. Aging and disease as modifiers of efficacy of cell therapy. Circ. Res. 2008, 102, 1319-1330. [CrossRef] [PubMed]

56. Edelberg, J.M.; Tang, L.; Hattori, K.; Lyden, D.; Rafii, S. Young adult bone marrow-derived endothelial precursor cells restore aging-impaired cardiac angiogenic function. Circ. Res. 2002, 90, E89-E93. [CrossRef] [PubMed]

57. Toma, C.; Pittenger, M.F.; Cahill, K.S.; Byrne, B.J.; Kessler, P.D. Human mesenchymal stem cells differentiate to a cardiomyocyte phenotype in the adult murine heart. Circulation 2002, 105, 93-98. [CrossRef] [PubMed]

58. Gnecchi, M.; Zhang, Z.; Ni, A.; Dzau, V.J. Paracrine mechanisms in adult stem cell signaling and therapy. Circ. Res. 2008, 103, 1204-1219. [CrossRef] [PubMed]

59. Weil, B.R.; Canty, J.M., Jr. Stem cell stimulation of endogenous myocyte regeneration. Clin. Sci. 2013, 125, 109-119. [CrossRef] [PubMed]

60. Kanashiro-Takeuchi, R.M.; Schulman, I.H.; Hare, J.M. Pharmacologic and genetic strategies to enhance cell therapy for cardiac regeneration. J. Mol. Cell. Cardiol. 2011, 51, 619-625. [CrossRef] [PubMed]

(C) 2016 by the authors; licensee MDPI, Basel, Switzerland. This article is an open access article distributed under the terms and conditions of the Creative Commons Attribution (CC-BY) license (http://creativecommons.org/licenses/by/4.0/). 